\title{
DIVERSIFIKASI PEKERJAAN SEBAGAI STRATEGI BERTAHAN HIDUP RUMAH TANGGA NELAYAN DI GALESONG UTARA
}

\author{
Hasriyanti Hasriyanti ${ }^{a}$, Hendra Hendra ${ }^{b}$ \\ ${ }^{a}$ Universitas Negeri Makassar, Jl. Dg. Tata Raya, Mallengkeri. Kota Makassar, Indonesia \\ ${ }^{b}$ Universitas Negeri Gorontalo, Jl. Prof. Dr. Ing. B.J Habibie, Kabupaten Bone Bolango, Provinsi Gorontalo 96119, \\ Indonesia
}

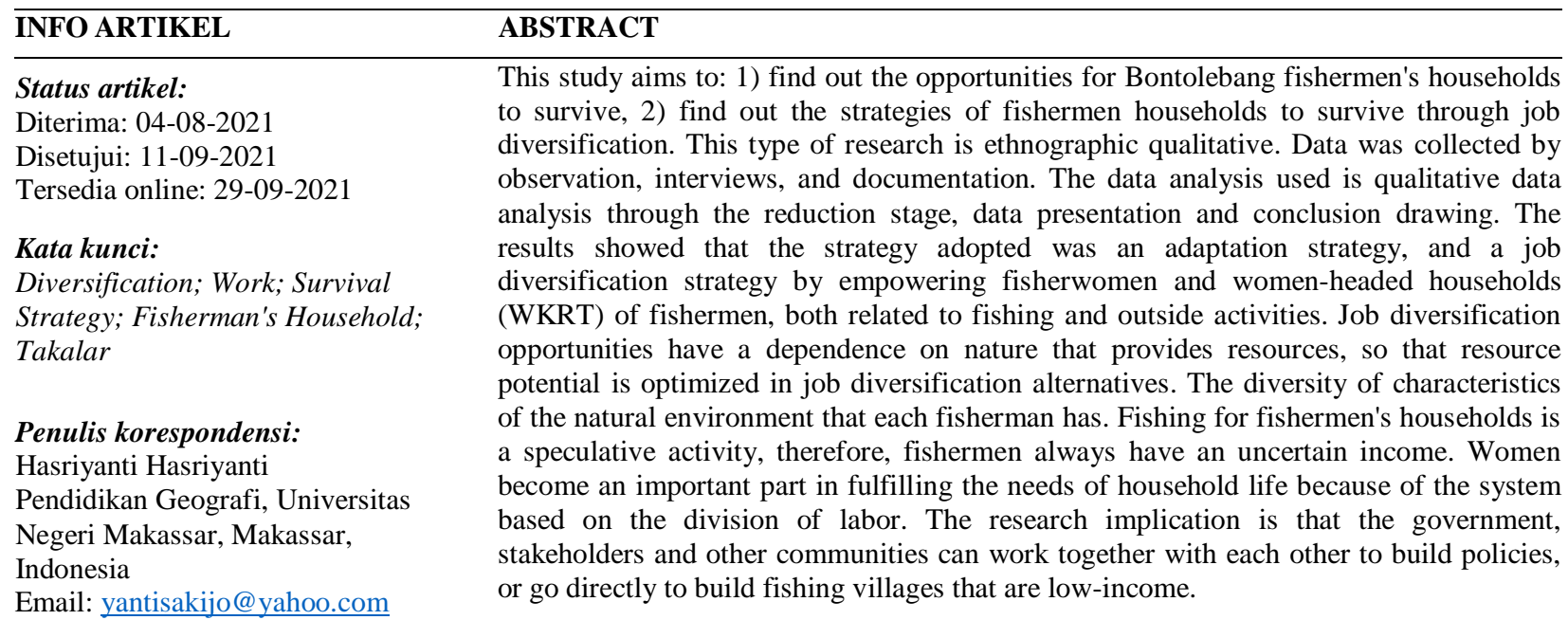

DOI: $10.34312 /$ jgej.v2i2.11349

Copyright () 2021 The Author(s)

\begin{abstract}
ABSTRAK
Penelitian ini bertujuan untuk: 1) mengetahui peluang rumah tangga nelayan Bontolebang untuk mempertahankan kelangsungan hidup, 2) mengetahui strategi rumah tangga nelayan untuk bertahan hidup melalui diversifikasi pekerjaan. Jenis penelitian ini adalah kualitatif etnografi. Pengumpulan data dilakukan dengan observasi, wawancara, dan dokumentasi. Analisis data yang digunakan yaitu analisis data kualitatif melalui tahap reduksi, penyajian data dan penarikan kesimpulan. Hasil penelitian menunjukkan bahwa strategi yang dilakukan adalah strategi adaptasi, dan strategi diversifikasi pekerjaan melalui pemberdayaan perempuan nelayan dan Wanita Kepala Rumah Tangga (WKRT) nelayan, baik yang terkait dengan kegiatan kenelayanan maupun diluarnya. Peluang diversifikasi pekerjaan memiliki ketergantungan pada alam yang menyediakan sumber daya, sehingga potensi sumber daya dioptimalkan dalam alternatif diversifikasi pekerjaan. Keragaman karakteristik lingkungan alam yang dimiliki setiap nelayan. Kegiatan melaut bagi rumah tangga nelayan merupakan kegiatan yang spekulatif, oleh karena itu, nelayan selalu memiliki penghasilan yang tidak menentu. Perempuan menjadi bagian penting dalam pemenuhan kebutuhan hidup rumah tangga karena adanya sistem berdasarkan pembagian kerja. Implikasi penelitian semoga pihak pemerintah, stakeholder dan masyarakat lainnya, secara bersama-sama dapat saling bekerja sama dengan membangun kebijakan, ataupun turun langsung membangun desa-desa nelayan yang ekonomi bawah.
\end{abstract}

This open access article is distributed under a Creative Commons Attribution-NonCommercial (CC-BY-NC) 4.0 International License

\section{Pendahuluan}

Masyarakat Bontolebang termasuk dalam kategori masyarakat yang begitu rumit. Pekerjaan sebagai nelayan adalah jalan kehidupan masyarakat. Sebagai nelayan, tentunya tidak jauh berbeda dengan masyarakat nelayan lainnya di berbagai daerah. Bahwa persoalan utama nelayan masih bergelut pada garis kemiskinan (Sianipar \& Pinem, 2017; Suryaningsi, 2017). Faktor-faktor yang kompleks menjadi penyebab 
dalam hal keterbatasan sosial dan kemiskinan masyarakat nelayan. Faktor tersebut terkait hasil tangkapan yang tidak tetap, kurangnya tenaga kerja, modal produksi, hingga sampai pada jalur untuk menjual hasil tangkapan nelayan yang masih terbatas (Hasriyanti, 2013; Kobi \& Hendra, 2020; Zebua et al., 2016). Karakteristik desa nelayan memiliki akses dan kemampuan sumber daya manusia yang berbeda-beda baik antar individu maupun antara masyarakat satu dengan yang lain.

Perbedaan kondisi setiap nelayan menuntut mereka mengatur strategi yang tepat untuk memenuhi kelangsungan hidupnya. Apalagi jumlah anak dalam keluarga banyak. Dimana tingkat fertilitas masyarakat nelayan di daerah tertentu dalam kategori tinggi (Susilo, 2015). Sehingga kebutuhan rumah tangga juga semakin besar. Meskipun didukung sumberdaya laut yang besar dan sebagai negara maritim (Suciani et al., 2021) namun dampak iklim menjadikan tangkapan bisa menurun (Marbun, 2020). Kondisi ini menjadikan mereka bekerja dibawah tekanan mental yang terus menerus untuk menghasilkan lebih banyak dan lebih banyak lagi untuk mencari nafkah dan sumber keuangan mereka (Chaudhry \& Chaudhry, 2012). Kemisikinan selalu jadi polemik pada kalangan nelayan, kesulitan untuk menghidupi keluarganya. Nelayan masih terbatas dalam berbagai hal, yang terlihat seperti terasing secara kemampuan karena fisiknya tidak mungkin terisolasi. Kemampuan nelayan yang dianggap tidak berkembang jika diperadapkan pada kegiatan ekonomi yang menguntungkan dan jejaring diluar organisasinya sebagai sebuah komunal (Mubah, 2011)

Gambaran kondisi nelayan terlihat dalam kehidupan yang terbatas secara materi, rumah dan pemukiman yang kurang berkualitas. Komunal nelayan dengan mudah dikenali sebagai masyarakat kekurangan dari rumah-rumah mereka. Rumah sederhana dan terkadang jauh dari kata layak. Bahan material rumah tidak permanen, atap, dinding dan lantai. Selain dalam hal kondisi hunian, kondisi kemiskinan nelayan digambarkan juga pada kondisi pendidikan yang rendah hingga untuk makanan sehari-hari jauh dari pendapatan yang layak. Beberapa kondisi rumah yang layak, hanya terlihat pada pemilik perahu tangkapan atau yang memiliki status sebagai pedagang ikan yang cukup sukses (Hasriyanti et al., 2010) dan memiliki jaringan kolektif yang baik (Hasriyanti, 2019).

Kajian tentang strategi bertahan hidup telah banyak dibahas dalam berbagai topik, namun kajian strategi yang dijalankan oleh masyarakat Bontolebang memiliki karakteristik msyarakat yang berbeda, sosial dan budaya yang kuat menjadi modal sosial untuk mempertahankan kehidupannya. Desa Bontolebang di Kecamatan Galesong Utara Kabupaten Takalar Sulawesi Selatan menjadi salah satu desa nelayan dengan karekteristik sosial ekonomi yang beragam sehingga mendorong mereka untuk menemukan strategi diversifikasi pekerjaan yang tepat sesuai karakteristik masyarakatnya.

\section{Metode}

Penelitian ini mengambil lokasi di salah satu desa nelayan, di Desa Bontolebang Kecamatan Galesong Utara Kabupaten takalar. Pelaksanaan penelitian dilakukan pada tahun 2021 dengan menggunakan informan kunci dan informan pendukung. Penelitian ini mengkaji tentang perilaku diversifikasi pekerjaan rumah tangga nelayan. Tipe penelitian adalah deskriptif dengan menggunakan pendekatan kualitatif. Pengumpulan data yang diperoleh melalui tinjauan observasi, wawancara dan tinjauan literatur serta dokumen. Data dianalisis melalui proses reduksi data, display data, dan verifikasi data.

\section{Hasil dan Pembahasan}

\subsection{Kegiatan Kenelayanan}

Pekerjaan sebagai nelayan merupakan pekerjaan yang dilakukan secara turun temurun dan pekerjaan tersebut dilakukan oleh sebagian besar penduduk. Menurut penuturan kepala desa Bontolebang, jumlah yang penghidupannnya tergantung dari sektor kenalayanan jumlahnya sekitar 70\%. Nelayan di desa Bontolebang secara garis besar dibagi dalam tiga kategori, yakni nelayan juragan/ pemilik perahu, buruh nelayan dan nelayan perseorangan. Nelayan juragan atau nelayan pemilik adalah pemilik alat tangkap, yaitu berupa perahu beserta paralatan tangkapannya seperti jaring. Buruh nelayan adalah mereka yang mengoperasikan alat tangkap bukan miliknya sendiri, yang di daerah setempat disebut pandega atau bandega. Nelayan perseorangan adalah nelayan yang memilliki peralatan tangkap sendiri, yang dalam pengoperasiannya tidak melibatkan orang lain (Hasriyanti, 2014). Dari tiga kategori nelayan tersebut, yang terbanyak jumlahnya di desa Bontolebang adalah nelayan perseorangan.

Alat tangkap yang digunakan nelayan desa Bontolebang meliputi bermacam-macam jaring, yaitu jaring gondrong, jaring selangkek, jaring setet, jaring kejer, dan jaring belanak. Dengan penggunaan berbagai jenis jaring jaring ini maka jenis ikan yang ditangkap juga bermacam-macam. Misalnya dengan jaring gondrong akan tertangkap rajungan, jaring selangket untuk menangkap ikan bagat dan ikan sisik, dan jaring belanak 
untuk menangkap ikan belanak. Masyarakat nelayan hanya dengan alat traditional untuk menangkap ikan (Syuryani, 2017). Dengan alat tangkap dan wilayah penangkapan yang penuh keterbatasan, hanya di sekitar perairan pantai. Selain itu, ketergantungan terhadap alam (musim) untuk para nelayan, sehingga terkadang tidak turun untuk melaut, di beberapa kondisi ini diperparah jika musim penghujan datang. Mengenal perahu yang digunakan nelayan di desa Bontolebang, pada dasarnya dibedakan dalam tiga kategori, yaitu perahu kecil yang diawaki oleh 2 orang, biasanya pemilik perahu itu sendiri dengan dibantu oleh seorang anak buah, bahkan kadang-kadang satu perahu hanya diawaki satu orang. Kedua, adalah perahu yang agak besar, yang biasanya diawaki oleh sekitar enam hingga delapan orang. Dan ketiga, adalah perahu yang lebih besar yang diawaki oleh sekitar 12 orang. Namun yang paling banyak digunakan adalah perahu kecil, yang mencakup sekitar $80 \%$ nelayan. Sementara untuk perahu sedang jumlahnya ada sekitar 15 buah, sedangkan perahu yang paling besar hanya ada dua buah.

Wilayah penangkapan nelayan desa Bontolebang umumnya di perairan dekat pantai, sesuai dengan jenis perahu dan alat tangkapan yang digunakan. Hal ini disebabkan karena perahu yang digunakan tergolong kecil, yaitu umumnya berkekuatan di bawah 6 GT. Jadi hanya bisa beroperasi di jalur perairan I (kurang dari 3 mil), dan untuk perahu yang agak besar beroperasi di jalu II (sekitar 7 mil dari pantai).

Nelayan dengan perahu kecil (dengan 2 awak) biasanya berangkat melalui sekitar pukul 00.00 hingga 02.00 malam. Jika berangkat lebih kemudian berarti wilayah tujuan penangkapan dekat. Penentuan daerah penangkapan yang akan dituju ditetapkan berdasarkan pengalaman melaut pada hari sebelumnya, baik pengalaman dirinya sendiri, maupun teman sesama nelayan. Pilihan lokasi penangkapan seringkali bersifat spekulasi, karena jenis ikan berada di dalam/dasar laut, nelayan tidak mudah mengidentifikasi keberadaannya.

Musim penangkapan ikan seccara turun temurun telah dilakukan, dalam setahun dimulai dari musim awal, dilanjutkan dengan musim panen, yang sangat tidak di inginkan adalah musim paceklik dimana ikan pada musim itu tidak ada ikan untuk ditangkap. Dalam tahun kalender dimulai dari Oktober-November (Awal) pada bulan selanjutnya memasuki Desember sampai pada tiga bulan kedepannya yaitu bulan Maret dikategorikan kedalam musim panen. Musim saat ikan tidak ada atau hasil tangkapan berkurang terjadi pada bulan April-September, terhitunga sebanyak 5 bulan nelayan akan kesulitan pada musim tersebut. Walaupun demikian, perhitungan tersebut biasanya fluktuatif atau tidak tetap, sangat bergantung pada peralihan musim (kemarau-penghujan) (Hasriyanti \& Syarif, 2021). Dengan demikian, nelayan akan merasakan musim terbaiknya hanya selama lima bulan, selebihnya mereka harus melakukan adaptasi dan tetap bertahan.

\subsection{Diversifikasi Pekerjaan sebagai Strategi untuk Mempertahankan Kelangsungan Hidup}

Temuan dilapangan mengemukakan bahwa bertahan hidup dengan diversifikasi pekerjaan adalah salah satu jalan untuk mempertahankan kehidupannya. Diversifikasi merupakan berpikir alternatif lainnya yang lebih luas. Matapencaharian yang dilakukan nelayan, baik bekerja di laut maupun didarat atau lainnya (Aris, 2005). Ragam lapangan pekerjaan tersedia untuk nelayan, namun hal tersebut sangat bergantung dari potensi sumber daya yang ada, dan tentu saja keterampilan yang dibutuhkan. Kerentanan rumah tangga sangat dipengaruhi oleh pendapatan yang rendah (Rukayah et al., 2014). Karakteristik lingkungan alam dan lingkungan sosial ekonomi yang beragam, yang menjadikan kondisi nelayan setiap desa selalu berbeda-beda. Sebagai sebuah desa yang tidak jauh dari kota Makassar, peluang untuk melakukan diversifikasi pekerjaan, terutama di sektor perdagangan maupun jasa cukup besar. Nelayan yang berada di Kota melakukan perluasan pekerjaan selain menjadi nelayan (Amir, 2018). Kegiatan di sektor tersebut memang telah dilakukan oleh sabagian warga, meskipun jumlahnya relatif sedikit. Pekerjaan mengayuh becak dan bekerja apapun baik sebagai tenaga buruh mereka kerjakan. Kesempatan kerja lain yang bisa dilakukan penduduk adalah sebagai petani atau buruh tani.

Sebagian wilayah desa merupakan lahan pertanian, khususnya terdapat di dusun Randulimo, sehingga sebagian warga melakukan pekerjaan sebagai petani. Profesi nelayan tetap menjadi profesi utama, dan tidak jauh dari aktifitas laut, berdagang ikan, pengolahan ikan hingga jenis sumber daya lainnya seperi kerang, tiram. Sebagiannya lagi bekerja menjadi tukang pembuat perahu, menyediakan fasilitas produksi nelayan seperti jaring tangkapan, kebutuhan untuk melaut seperti bahan bakar, es pendingin dan alat kebutuhan untuk melaut lainnya. Sebaran diversifikasi pekerjaan masyarakat nelayan dapat dilihat pada gambar 1. 


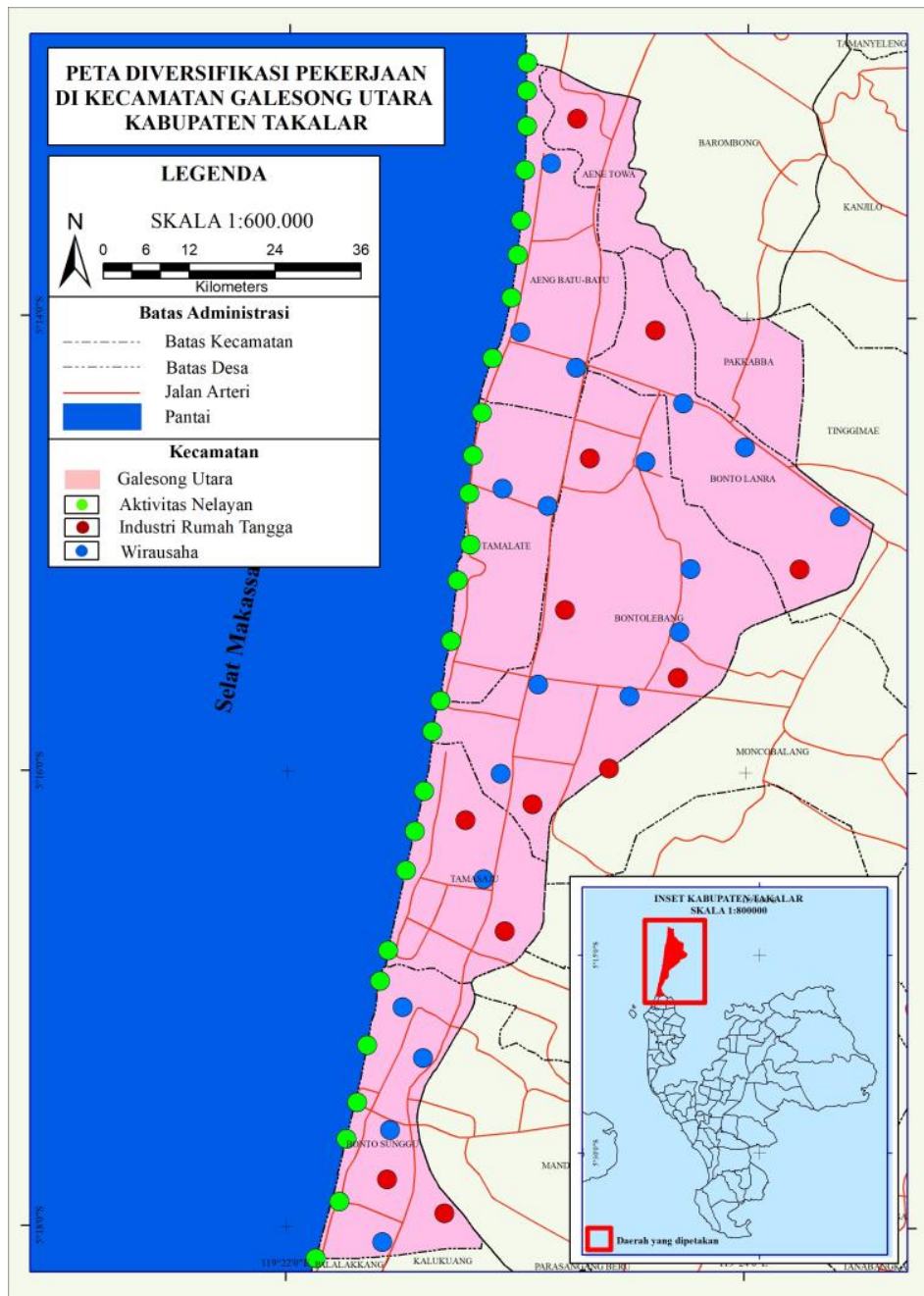

\section{Gambar 1. Peta Diversifikasi Pekerjaan Di Kecamatan Galesong Utara}

Bagi nelayan Bontolebang, prosesi yang dijalankan selama ini di luar aktifitas sebagai nelayan akan dilakukan oleh mereka saat tidak melaut. Walaupun hanya sebagai pekerjaan sampingan namun pekerjaan ini sangat memberikan pengaruh untuk kebutuhan sehari-harinya. Pekerjaan sampingan bukan hanya di seriusi pada saat tidak melaut tetapi mereka jadikan alternatif profesi yang berjalan turun temurun. Pekerjaan sampingan akan kembali ditinggalkan saat musim untuk menangkap ikan kembali membaik. Kontribusi kerja sampingan adalah alternatif dari strategi bertahan hidup nelayan yang hidup dalam ketidakpastian penghasilan setiap tahunnya.

Berdagang ikan merupakan salah satu pekerjaan yang banyak dilakukan oleh isteri nelayan. Mereka bahkan ada yang melakukan pekerjaan tersebut sepanjang tahun. Istri nelayan merupakan padagang ikan antar kota di Sulawesi selatan. Pekerjaan mengasinkan/ mengawetkan ikan dengan cara menjemur di terik matahari juga merupakan pekerjaan sampingan yang biasanya dilakukan oleh istri nelayan yang dibantu oleh anak-anaknya. Kerja keluarga telah dijalankan sebagai kesepakatan tidak tertulis dalam keluarga nelayan. Keterlibatan semua anggota keluarga dalam setiap pekerjaan. Keterlibatan anak-anak juga dapat dilihat pada kehidupan nelayan Bontolebang. Anak-anak mereka akan memberikan kontribusinya pada kegiatan di darat, seperti pengelolaan ikan, mengasinkan hingga untuk anak-anak laki-laki akan ikut turun ke laut membantu walaupun hanya sekedar membantu membersihkan perahu, alat tangkapan hingga menyediakan perlengkapan lainnya. Pekerjan-pekerjaan yang bersifat tidak membutuhkan tenaga ringan akan dilakukan oleh para anak perempuannya. Masyarakat nelayan memahami bahwa melakukan diversifikasi pekerjaan merupakan aktivitas yang penting untuk membantu kebutuhan sosial ekonomi mereka (Hasriyanti, 2014). $\mathrm{Hal}$ in terkait dengan keterbatasan aktivitas melaut yang tidak bisa dilakukan sepanjang tahun. Umumnya profesi neleyan tidak menjadi satu-satunya pekerjaan tetapi diluar dari itu, mereka melakukan pekerjaan lainnya. 


\subsection{Strategi Adaptasi dan Peranan Wanita Nelayan}

Kemisikinan pada dasarnya akan memaksa seluruh potensi yang dimiliki, seluruh asset akan digunakan untuk mempertahankan kehidupan dari goncangan kondisi ekonomi (tekanan) (Chaudhry \& Chaudhry, 2012). Seperti halnya kondisi yang dialami oleh para korban PHK, korban bencana dan beberapa kondisi lainnya yang di akibatkan oleh krisis. Tekanan ini akan memberi pengaruh terhadap perilaku masyarakat untuk melakukan adaptasi secara menyeluruh jikan ingin tetap melangsungkan kehidupannya. Ketidak adilah kebijakan yang di terima masyarakat biasa terjadi sehingga setiap aset yang dimiliki akan menjadi bagian dari pertukaran kehidupan. Harta benda akan di gadaikan, dijual hingga bisa dijadikan modal awal dalam mempertahankan kehidupannya. Istri-istri nelayan akan menjadikan solusi menjual harta benda sebagai salah satu alternatif.

Komunitas yang terbangun dalam kehidupan perempuan nelayan dijadikan sebagai komunitas untuk saling bertukar, saling sharing dan membentuk perkumpulan, salah satu kegiatan yang mereka lakukan adalah konsep arisan. Konsep yang dilakukan untuk bertukar modal, atau harta yang telah disepakati untuk saling membantu. Setiap periode tertentu akan bergantian untuk saling bertukar kekayaan, baik uang, alat dapur maupun lainnya yang dijadikan kesepakatan dalam komunitas arisan oleh ibu-ibu nelayan. Komunitas pengajian, hingga pada kegiatan simpan pinjam. Adapatasi keorganisasi yang dilakukan semata-mata langkah konkrit untuk menyelesaikan persoalan ekonomi yang rumit. Kegiatan perempuan ini dibangun dari pranata-pranata sosial ekonomi yang dianggap memberikan alternatif. Strategi adaptasi yang dilakukan oleh para istri nelayan termasuk dalam konsep strategi adaptasi. Langkah alternatif yang dianggap rasional dalam kehidupan sosial untuk penduduk miskin atau tertekan secara ekonomi.

\subsection{Peranan Perempuan Pesisir}

Strategi adaptasi perempuan pesisir yang dijalankan melewati batas-batas pekerjaannya, kegiatan publik dan lainnya telah dilakukan. Keterlibatan perempuan dan pembagian kerja yang telah dirawat, sebagai bagian yang membatasi antara ranah perempuan dan laki-laki. Perempuan dan laki-laki nelayan memiliki tanggung jawab masing-masing. Tetapi dalam hal profesi kerja, mereka sama-sama mencari nafkah karena penghasilan nelayan dari suaminya tidak mampu mempertahankan kehidupannya secara layak. Keterlibatan istri nelayan dalam kegiatan publik telah dijalankan selama ini. Sistem pembagian kerja secara gender yang berlaku didalam masyarakat nelayan, dimana tugas-tugas di darat sepenuhnya menjadi tanggung jawab perempuan termasuk istri dan anak perempuan nelayan. sedangkan laut merupakan ranah laki-laki (suami), telah memberikan peluang besar bagi perempuan untuk berkontribusi bagi keluarganya dengan melibatkan diri dalam kegiatan publik.

Peranan domestik perempuan adalah peranan sosial yang terkait dengan aktivitas internal rumah tangga, seperti memasak, mengurus anak, dan melayani suami. Jika kedua peranan tersebut dapat dilakukan oleh seorang perempuan maka ia memainkan peranan ganda dalam kehidupan rumah tangga. Berbagai hasil penelitian mengenai kehidupan masyarakat nelayan umumnya memperlihatkan bahwa sebagian besar nelayan hidup dalam kemiskinan dan ketidakpastian perekonomian karena mereka menghadapi kendala khusus berupa gangguan alam, yaitu hubungan antara nelayan dan lingkungannya selalu diliputi ketidakpastian. Strategi sistem pembagian kerja dalam masyarakat nelayan yang memberikan keleluasan terhadap perempuan pesisir atau istri nelayan untuk terlibat dalam aktivitas sosial-ekonomi di luar rumah merupakan pilihan rasional yang oleh Tunstall disebut sebagai strategi adaptif (Hasriyanti, 2019). Strategi adaptif yang dipilih oleh masyarakat nelayan umumnya dengan melakukan pembagian kerja antara suami dan istri serta antar anggota rumah tangga nelayan yang lain atau anak-anak nelayan.

Peranan dominan yang dimainkan oleh perempuan pesisir yang tidak hanya bergelut dalam hal proses pengolahan ikan maupun perdagangan ikan (menjual). Secara ekonomi, perempuan telah banyak mengambil peran dalam memenuhi kebutuhan ekonomi (Setyawati, E Yuningtyas., Siswanto, 2020). Mendapatkan keuasaan dalam hal pengelolaan keuangan secara keselurhan pendapatan dan pengeluaran. Untuk konsumsi sehari-hari, pembelian pakaian, perabotan rumah tangga, menabung, perbaikan rumah, biaya pendidikan anak, dan sebagainya (Masyhuri, 2003). Di desa-desa nelayan seperti pesisir Galesong Utara yang berlaku mengharuskan suami untuk menyerahkan semua penghasilan yang diperolehnya kepada istri, suami tidak di perkenankan memegang penghasilannya sendiri. Temuan dilapangan menggambarkan dominannya perempuan dalam hal kedudukannya dan peran sosial yang strategis yang dijalankannya, baik dalam keluarga maupun yang menyangkut keterlibatan orang lain secara komunal. Kondisi tersebut terjadi akibat posisi perempuan yang memerankan banyak hal di darat dibandingkan suaminya dalam kegiatan sosial- 
ekonomi di darat, terutama kegiatan perdagangan ikan, sedangkan kegiatan melaut merupakan pekerjaan laki-laki.

Peran gender yang berlaku dalam tatanan kehidupan masyarakat nelayan. Peran ini memberikan dampak pada kaum perempuan yang terlibat dalam berbagai hal untuk kelangsungan hidup keluarga. Peran perempuan pesisir yang dilakukan untu membantu pendapatan keluarga. Melaut adalah pekerjaan nelayan yang tidak menentu, sehingga penghasilan untuk nelayan sangat fluktutif sangat bergantung pada musim (Hasriyanti, 2013). Ketidakpastian pendapatan yang diterima oleh nelayan menekan peran perempuan untuk memberikan hidup mereka untuk menopang pendapatan suami yang seret pada musim paceklik. Sektor usaha ekonomi itulah yang selama ini banyak diperankan oleh istri nelayan. Terutama kegiatan pengeringan dan pemindangan ikan. Hal tersebut terkait dengan hasil penelitian di desa nelayan di wilayah pesisir Bawean, istri nelayan lebih banyak melakukan kegiatan seperti, mengolah ikan, mulai dari menimbang, mencuci, memotong, menusuk potongan ikan dengan tusuk sate, memanggang, menata ikan panggangan di Nyiur sampai menjualnya kepasar atau kawasan perumahan (menjual kerumah) (Masyhuri Imron, 2003). Istri nelayan yang bertanggung jawab mengolah dan menjual ikan. Alasan mereka menjual ikan karena pekerjaan tersebut adalah kewajibannya sebagai istri dan merupakan kesepakatan bersama dengan suami.

Bagi istri-istri nelayan yang membuka usaha warung makanan-minuman, tingkat pendapatan yang diperoleh juga sangat tergantung dari fluktuasi pendapatan nelayan dari kegiatan melaut. Strategi bertahan hidup yang diterapkan oleh ibu rumah tangga nelayan adalah usaha wiraswasta seperti membuka warung (Harini \& Listyaningsih, 2001). Usaha warungnya itu akan menghadapi masa sepi jika musim paceklik atau masa terang bulan tiba. Pada masa ini, penghasilan nelayan dari melaut tidak bisa dipastikan, sehingga mempengaruhi tingkat konsumsinya.

\subsection{Peran Wanita Kepala Rumah Tangga (WKRT)}

Kepala rumah tangga wanita menjalankan peran yang lebih banyak. Strategi bertahan yang dilakukan pada musim krisis tangkapan akan berdampak pada pendapatan. Usia adalah faktor yang menjadikan semuanya menjadi sulit, selain modal, keterampilan mereka juga sangat terbatas. Walaupun berani mengambil keputusan untuk berdagang ataupun yang membutuhkan modal, mereka tidak ingin rugi banyak jika keputusan itu diambil.

Masyarakat di desa Bontolebang banyak mengembangkan usaha membuka warung sedangkan bagi keluarga yang berada sedikit ke arah pinggiran kota, membuka usaha wiraswasta yaitu usaha kost, menjahit, salon, mendirikan warteg dan menjadi tukang pijat. Beberapa kasus yang terjadi wanita kepala rumah tangga hanya bergantung pada orang lain, bantuan makanan dan lainnya. Tekanan ini yang dirasakan oleh mereka untuk mencari alternatif dan ikut terlibat dalam sektor industri.

\section{Kesimpulan}

Pelaksanaan penelitian memperoleh beberapa kesimpulan bahwa strategi yang dijalankan masyarakat nelayan bontolebang cukup beragam. Strategi yang dijalankan oleh mereka adalah sistem diversifikasi, potensi untuk alterntif memperluas profesi kerja cukup besar, karena dekat kota besar. Sistem gender, memberdayakan perempuan nelayan dan wanita kepala rumah tangga (WKRT) nelayan dijankan semaksimal mungkin, baik yang terkait dengan kegiatan kenelayanan maupun di luar aktivitas nelayan. Untuk melakukan diversifikasi pekerjaan tergantung pada sumber-sumber daya yang tersedia di desa nelayan yakni di desa Bontolebang. Setiap desa nelayan memiliki karakteristik lingkungan alam yang tidak sama. Diversifikasi pekerjaan bagi keluarga nelayan membawa dampak besar dan berarti untuk memperpanjang hidup keluarganya. Hal ini tekait dengan ketidakteraturan dan ketidakstabilan penghasilan nelayan dari hasil melaut.

\section{Referensi}

Amir, M. F. (2018). Strategy of Survive the Fishermen Laborers in Barombong Tamalate Sub-district, Makassar City. 16(2).

Aris. (2005). Pengelolaan Wilayah Pesisir dan Laut Desa. PT. Pradnya Paramita.

Chaudhry, A. G., \& Chaudhry, H. ur R. (2012). Indigenous Model of Sustainable Development: A Case Study of Techno-Traditional Wisdom in a Punjabi Village. Journal of Gender \& Social Issues, 11(1), 39-60.

http://ezproxy.lib.ucalgary.ca/login?url=http://search.ebscohost.com/login.aspx?direct=true \&db=sih\&A 


\section{$\mathrm{N}=88302341 \&$ site $=$ ehost-live}

Harini, R., \& Listyaningsih, U. (2001). Perubahan Strategi Bertahan Hidup Wanita Kepala Rumah Tangga Di Masa Krisis (Studi Kasus Kecamatan Umbulharjo Daerah Istimewa Yogyakarta). Majalah Geografi Indonesia, 15(1), 47-62.

Hasriyanti. (2013). Analisis Pemanfaatan Ruang Dalam Pengelolaan Sumber Daya Pesisir Di Desa Lero Kecamatan Suppa Kabupaten Pinrang.

Hasriyanti. (2014). Pemetaan Wilayah Produksi Rumput Laut di Kecamatan Tamalatea Kabupaten Jeneponto. III(2), 176-184.

Hasriyanti. (2019). Fisherman Perception According to Social Stratification on Child Education in Aeng Batu-batu Village , North Galesong District , Takalar District. LA GEOGRAFIA, 17(2), 87-93. https://ojs.unm.ac.id/Lageografia/article/view/8207

Hasriyanti, Leo, Z., Syarif, E., \& Prasad, H. H. (2010). Model Pemberdayaan Rumah Tangga Nelayan Buruh Miskin Untuk Pengembangan Usaha Budidaya Perairan Pesisir di Sulawesi selatan.

Hasriyanti, \& Syarif, E. (2021). Strategi Pemberdayaan Sumber Daya Laut Melalui Kearifan Lokal Sistem Punggawa-Sawi Di Desa Palalakkang Kecamatan Galesong Kabupaten Takalar. Jurnal Environmental Science, 3(2), 8-17.

Kobi, W., \& Hendra, H. (2020). Kajian geografi ekonomi: studi kasus kondisi sosial ekonomi masyarakat suku bajo di popayato, gorontalo. Jambura geo education journal, 1(1), 16-25. https://doi.org/10.34312/jgej.v1i1.4637

Marbun, F. (2020). Adaptation Strategies of Traditional Fishermen in Sutera Sub-District, Pesisir Selatan Regency on Climate Change. Jurnal Ilmu Sosial Mamangan, 9(1), 1-16. https://doi.org/10.22202/mamangan.v9i1.3394

Masyhuri Imron. (2003). Kemiskinan Dalam Masyarakat Nelayan. Jurnal Masyarakat Dan Budaya, 5(1), 63-82. https://jmb.lipi.go.id/jmb/article/download/259/237/503

Mubah, A. S. (2011). Strategi Meningkatkan Daya Tahan Budaya Lokal dalam Menghadapi Arus Globalisasi. Tahun, 24(031), 302-308.

Rukayah, S., Yunus, H. S., \& Listyaningsih, U. (2014). Strategi Penghidupan Rumah Tangga Di Kecamatan Patamuan Kabupaten Padang Pariaman Pasca Gempa Bumi Tahun 2009. Majalah Geografi Indonesia, 28(2), 172-178.

Setyawati, E Yuningtyas., Siswanto, R. S. H. P. (2020). Partisipasi perempuan dalam pengelolaan sampah bernilai ekonomi dan berbasis kearifan lokal. Geo, Jambura Journal, Education, 1(2), 55-65. https://doi.org/10.34312/jgej.v1i2.6899

Sianipar, T., \& Pinem, K. (2017). Strategi Bertahan Hidup Keluarga Nelayan Danau Toba Di Desa Lumban Binanga Kecamatan Laguboti Kabupaten Toba Samosir. Tunas Geografi, 6(2), 159. https://doi.org/10.24114/tgeo.v6i2.8672

Suciani, A., Effendi, D. I., \& Z, S. (2021). Geography Learning Media Based On Character Education In The Digital Revolution Era. Jurnal Geografi, 13(2).

Suryaningsi, T. (2017). Poverty of Fisherman Society in Aeng Batu-Batu. Jurnal Handep, 1(1), 49-62.

Susilo, S. (2015). Fertilitas Masyarakat Nelayan di Desa Banjarkemuning Kabupaten Sidoarjo. Jurnal Pendidikan Geografi, 20(2), 46-52. https://doi.org/10.17977/um017v20i22015p046

Syuryani. (2017). Strategi bertahan hidup rumah tangga nelayan tradisional dalam mengatasi kemiskinan. Jurnal Ilmu Sosial Dan Ilmu Politik, 4(2), 1-15.

Zebua, Y., Wildani, P. K., Lasefa, A., \& Rahmad, R. (2016). Faktor Penyebab Rendahnya Tingkat Kesejahteraan Nelayan Pesisir Pantai Sri Mersing Desa Kuala Lama Kabupaten Serdang Bedagai Sumatera Utara. Jurnal Geografi, 9(1), 88. https://doi.org/10.24114/jg.v9i1.6923 